\title{
MOVEMENT COORDINATION: IDENTIFICATION OF DEVELOPMENT PECULIARITIES IN GIRLS AND BOYS AGED 11-13
}

\author{
Ivashchenko O. ${ }^{1}$, Khudolii O. ${ }^{1}$, Iermakov S. ${ }^{2}$, Bartík P. ${ }^{3}$, Prykhodko V. ${ }^{4}$ \\ ${ }^{1}$ H. S. Skovoroda Kharkiv National Pedagogical University, Ukraine \\ ${ }^{2}$ Gdansk University of Physical Education and Sport, Poland \\ ${ }^{3}$ Matej Bel University, Banska Bystrica, Slovakia \\ ${ }^{4}$ Start-School, Kharkiv, Ukraine
}

Corresponding Author: Ivashchenko Olha, e-mail: olga@tmfv.com.ua

Accepted for Publication: September 15, 2018

Published: September 25, 2018

DOI:10.17309/tmfv.2018.3.04

\begin{abstract}
The study objective is to determine the possibility of identifying the state of coordination abilities development in girls and boys aged 11-13 using the methodology of multidimensional statistics.

Materials and methods. Study participants. The study involved girls: $11(\mathrm{n}=20), 12(\mathrm{n}=23), 13(\mathrm{n}=19)$ years old; boys: $11(\mathrm{n}=21), 12(\mathrm{n}=20), 13(\mathrm{n}=19)$ years old.

Study organization. The paper used analysis and generalization of scientific literature data, testing, discriminant analysis. Testing procedure. The testing program included well-known tests (Liakh, 2000; Serhiienko, 2001; Ivashchenko, 2016).

Study results. The first canonical function explains $65.7 \%$ of the results variation, the second one $-25.1 \%$, the third $-4.8 \%$, which indicates their informative value. The coefficients of canonical correlation indicate the prognostic value of these functions. The first canonical discriminant function is most substantially related to the results of tests $4(\mathrm{r}=0.526), 14(\mathrm{r}=0.377), 2(\mathrm{r}=-0.306)$ : therefore, a significant difference between the girls and boys aged 11-13 is observed in the development level of relative and speed strength, movement coordination. The structure coefficients of the second canonical discriminant function indicate that the function is most substantially related to variables $2(r=0.502), 16(r=0.434), 9(r=0.379), 17$ $(\mathrm{r}=0.357)$ : so, a significant difference between the girls aged 12-13 and boys aged 11-13 is observed in speed strength, vestibular stability, and anthropometric data.

Conclusions. The discriminant models characterize both age- and gender-related peculiarities of movement coordination development in the girls and boys aged 11-13. The data obtained show significant differences between the groups of girls and boys aged 11-13 both in the structure of coordination abilities development and the level of preparedness, and highlight the need to conduct separate physical education classes for girls and boys. Different programs should be used to develop coordination abilities in boys and girls aged 11-13.
\end{abstract}

Keywords: discriminant analysis, coordination abilities, comprehensive control, girls, boys

\section{Introduction}

One of the key tasks of the modern school is to develop motor function in schoolchildren. Data on age- and gender-related regularities of motor function development provide background for organizing physical education of children and adolescents. Physical activity and its impact on population health is one of the research problems in physical education (Bădicu, \&Balint, 2016; Bădicu, 2018). Physical education of schoolchildren aims at developing children's motor

(C) Ivashchenko O., Khudolii O., Iermakov S, Bartík P., Prykhodko V., 2018. function and includes: optimizing children's physical development (Balsevich, 2000; Ilyin, 2003), improving their motor abilities, promoting and protecting their health (Ivashchenko, 2016; Emeljanovas, Mieziene, \& Putriute, 2015), developing motor skills (Han, Fu, Cobley, \& Sanders, 2017). Coordination abilities belong to the basic abilities and can be developed in school age (Balsevich, 2000; Liakh, 2000).

Numerous studies have reached conclusions on the following points:

- the effectiveness of comprehensive development of motor abilities in children (Liakh, 2000; Krutsevych, \& Bezverkhnia, 2010); 
- the influence of movement coordination level on building motor skills in schoolchildren (Khudolii, Ivashchenko, \& Chernenko, 2015; Ivashchenko, 2016; Kapkan, 2015);

- the interrelation of anthropometric, motor and cognitive abilities in children (Iadreev, Cherkashin, Vujkov, \& Drid, 2015; Novak, Podnar, Emeljanovas, \& Marttinen, 2015);

- the relationship between the body mass index, subcutaneous fat and the manifestation of movement coordination in children aged 1114 (Drid, Vujkov, Jaksic, Trivic, Marinkovic, \&Bala, 2013; Han, A., Fu, A., Cobley, S., \& Sanders R. H., 2017);

- the influence of visual perception on children's movement coordination of different parts of the body (Agricola, Psotta, Abdollahipour, \& Nieto, 2015; Palomo-Nieto, Psotta, Agricola, Abdollahipour, \& Valtr, 2015);

- the effect of physical activity modes on the plasticity of motor skills in schoolchildren (Hadžić, Bjelica, Vujović, \& Popović, 2015; Khudolii, \& Ivashchenko, 2014).

When studying the structure of schoolchildren's motor preparedness, it is effective to use multidimensional methods of mathematical statistics, such as factor and discriminant analyses (Ivashchenko, 2016; Lopatiev, Ivashchenko, Khudolii, Pjanylo, Chernenko, \& Yermakova, 2017). Discriminant analysis also proved effective for studying the training process of athletes (Doğan, Işik, \& Ersöz, 2016; Miarka, Fukuda, Del Vecchio, \& Franchini, 2016).

In available literature, however, there are not enough data on comparative analysis of coordination abilities development in girls and boys aged 11-13 years.

Therefore, it is relevant to study the peculiarities of dynamics of coordination abilities development by identifying their state of development in girls and boys aged 11-13.

The study objective is to determine the possibility of identifying the state of coordination abilities development in girls and boys aged 11-13 using the methodology of multidimensional statistics.

\section{Materials and methods}

Study participants. The study involved girls: 11 $(n=20), 12(n=23), 13(n=19)$ years old; boys: 11 $(\mathrm{n}=21), 12(\mathrm{n}=20), 13(\mathrm{n}=19)$ years old.

Study organization. The paper used analysis and generalization of scientific literature data, testing, methods of mathematical statistics.

Testing procedure. The testing program included well-known tests (Liakh, 2000; Serhiienko, 2001; Ivashchenko, 2016). To evaluate motor preparedness, the study recorded the results of motor tests, body height and weight:

- Test 1 "30 m running (s)";

- Test 2 "Standing long jump (cm)";

- Test 3 "Six standing accuracy ball handlings to a partner from a $7 \mathrm{~m}$ distance using one of the techniques learned";

- Test 4 "Pull-ups (number of times)";

- Test 5 "Sit-ups in 30 seconds";

- Test 6 "Evaluation of the sense of movement speed in sprinting";

- Test 7 "Evaluation of the ability to differentiate movement speed (reproduction accuracy of running speed at $80 \%$ intensity of maximum)";

- Test 8 "Evaluation of the ability to differentiate movement speed (reproduction accuracy of running speed at $90 \%$ intensity of maximum)";

- Test 9 "Static equilibrium evaluation by E. Ya. Bondarevsky's method";

- Test 10 "Evaluation of dynamic equilibrium by the BESS method";

- Test 11 "Evaluation of the ability for vestibular (statokinetic) stability. Running with turns";

- Test 12 "Rhythmic hand tapping";

- Test 13 "Rhythmic movements of upper and lower limbs";

- Test 14 "Shuttle run $(4 \times 9 \mathrm{~m})$ ";

- Test 15 "Tossing a ring over a peg";

- Test 16 "Height $(\mathrm{cm})$ ";

- Test 17 "Body weight (kg)".

Statistical analysis. The study materials were processed by the IBM SPSS 20 statistical analysis software. In the process of discriminant analysis, the study created a prognostic model for group membership. This model develops a discriminant function (or, when there are more than two groups - a set of discriminant functions) in the form of a linear combination of predictor variables, ensuring the best division of groups. These functions are developed according to a set of observations, for which their group membership is known. These functions can continue to be used for new observations with known values of predictor variables and unknown group membership.

For every variable, the study calculated the following: mean values, standard deviations, singlefactor dispersion analysis (Box's $M$ test, in-group correlation matrix, in-group covariance matrix, covariance matrices for separate groups, general covariance matrix). For every canonical discriminant function, the study calculated: eigenvalue, dispersion percentage, canonical correlation, Wilks' Lambda, Chisquare. For every step, it calculated: prior probabilities, Fisher's function coefficients, unstandardized function coefficients, Wilks' Lambda for every canonical function. 
Table 1. Results of Comparative Analysis of Coordination Preparation of Girls and Boys Aged 11-13

\begin{tabular}{|c|c|c|c|c|c|c|c|c|}
\hline \multirow{2}{*}{ No } & \multirow{2}{*}{ Test } & \multirow{2}{*}{ Aged } & \multicolumn{2}{|c|}{ Girls } & \multicolumn{2}{|c|}{ Boys } & \multirow{2}{*}{$\mathrm{t}$} & \multirow{2}{*}{$\mathrm{P}$} \\
\hline & & & $\mathrm{X}$ & $\mathrm{s}$ & $\mathrm{X}$ & $\mathrm{s}$ & & \\
\hline \multirow[t]{3}{*}{1} & $30 \mathrm{~m}$ running $(\mathrm{s})$ & 11 & 7,06 & 45 & 6,45 &, 38 & 4,740 & $<0,001$ \\
\hline & & 12 & 6,86 &, 39 & 6,28 & ,35 & 5,078 & $<0,001$ \\
\hline & & 13 & 6,65 &, 43 & 6,29 &, 37 & 2,704 & $<0,010$ \\
\hline \multirow[t]{3}{*}{2} & Standing long jump (cm) & 11 & 124,75 & 9,09 & 138,90 & 11,94 & $-4,253$ & $<0,001$ \\
\hline & & 12 & 128,48 & 10,99 & 150,50 & 10,69 & $-6,633$ & $<0,001$ \\
\hline & & 13 & 141,42 & 8,13 & 160,89 & 10,71 & $-6,315$ & $<0,001$ \\
\hline \multirow[t]{3}{*}{3} & Six standing accuracy ball handlings to a partner from & 11 & 2,30 & 1,08 & 4,14 & 1,35 & $-4,805$ & $<0,001$ \\
\hline & a $7 \mathrm{~m}$ distance using one of the techniques learned & 12 & 2,26 & ,96 & 3,40 & ,94 & $-3,910$ & $<0,001$ \\
\hline & & 13 & 2,16 & 1,01 & 3,68 & ,95 & $-4,796$ & $<0,001$ \\
\hline \multirow[t]{3}{*}{4} & Pull-ups (number of times) & 11 & 5,25 & 1,74 & 2,71 & ,85 & 5,972 & $<0,001$ \\
\hline & & 12 & 8,00 & 2,29 & 3,20 & 1,19 & 8,401 & $<0,001$ \\
\hline & & 13 & 10,32 & 2,60 & 4,00 & 1,33 & 9,409 & $<0,001$ \\
\hline \multirow[t]{3}{*}{5} & Sit-ups in 30 seconds & 11 & 14,00 & 3,04 & 19,67 & 5,05 & $-4,322$ & $<0,001$ \\
\hline & & 12 & 17,30 & 4,17 & 18,25 & 5,57 &,- 635 & $>0,529$ \\
\hline & & 13 & 17,32 & 4,84 & 21,84 & 4,47 & $-2,992$ & $<0,005$ \\
\hline \multirow[t]{3}{*}{6} & Evaluation of the sense of movement speed in sprinting & 11 &, 50 &, 18 & ,36 &, 14 & 2,745 & $<0,009$ \\
\hline & & 12 & ,38 & ,08 & ,37 & ,11 &, 211 & $>0,834$ \\
\hline & & 13 &, 31 & ,086 &, 33 & ,13 &,- 777 & $>0,442$ \\
\hline \multirow[t]{3}{*}{7} & Evaluation of the ability to differentiate movement & 11 & ,33 &, 12 & ,32 &, 12 & ,379 & $>0,706$ \\
\hline & speed (reproduction accuracy of running speed at $80 \%$ & 12 & ,30 &, 11 & ,29 & ,14 &, 251 & $>0,803$ \\
\hline & intensity of maximum) & 13 &, 37 & 09 & ,35 & ,09 & ,469 & $>0,642$ \\
\hline \multirow[t]{3}{*}{8} & Evaluation of the ability to differentiate movement & 11 &, 27 & 07 & 25 & ,09 &, 674 & $>0,504$ \\
\hline & speed (reproduction accuracy of running speed at $90 \%$ & 12 &, 31 & 09 &, 27 & 08 & 1,457 & $>0,153$ \\
\hline & intensity of maximum) & 13 & ,32 & ,07 & ,32 & ,09 & 0 & \\
\hline \multirow[t]{3}{*}{9} & Static equilibrium evaluation by E. Ya. Bondarevsky's & 11 & 34,80 & 11,27 & 28,64 & 11,25 & 1,753 & $>0,087$ \\
\hline & method & 12 & 38,59 & 8,88 & 31,54 & 10,08 & 2,437 & $<0,019$ \\
\hline & & 13 & 49,12 & 7,68 & 45,31 & 9,41 & 1,369 & $>0,179$ \\
\hline \multirow[t]{3}{*}{10} & Evaluation of dynamic equilibrium by the BESS & 11 & 42,65 & 8,58 & 40,05 & 5,67 & 1,150 & $>0,257$ \\
\hline & method & 12 & 36,30 & 8,06 & 39,70 & 6,12 & $-1,537$ & $>0,132$ \\
\hline & & 13 & 36,05 & 8,76 & 34,79 & 7,43 & ,479 & $>0,635$ \\
\hline \multirow[t]{3}{*}{11} & Evaluation of the ability for vestibular (statokinetic) & 11 & 4,75 & 1,13 & 4,24 & 1,12 & 1,443 & $>0,157$ \\
\hline & stability. Running with turns & 12 & 4,80 & ,99 & 4,48 & ,98 & 1,067 & $>0,292$ \\
\hline & & 13 & 5,42 & 1,17 & 4,52 & ,97 & 2,585 & $<0,014$ \\
\hline 12 & Rhythmic hand tapping & 11 & 5,65 & 1,72 & 5,38 & 1,39 &, 550 & $>0,585$ \\
\hline & & 12 & 5,78 & 1,54 & 6,40 & 1,73 & $-1,240$ & $>0,222$ \\
\hline & & 13 & 4,00 & 1,15 & 3,84 & ,95 & ,459 & $>0,649$ \\
\hline 13 & Rhythmic movements of upper and lower limbs & 11 & 4,25 & ,96 & 4,00 & 1,00 & 813 & $>0,421$ \\
\hline & & 12 & 4,48 & 1,12 & 4,70 & 1,13 &,- 644 & $>0,523$ \\
\hline & & 13 & 3,63 & 1,12 & 3,89 & 1,10 &,- 732 & $>0,469$ \\
\hline 14 & Shuttle run $(4 \times 9 \mathrm{~m})$ & 11 & 13,75 & ,97 & 12,48 &, 90 & 4,310 & $<0,001$ \\
\hline & & 12 & 14,22 & 1,06 & 12,45 & ,95 & 5,727 & $<0,001$ \\
\hline & & 13 & 14,16 & 1,18 & 11,35 &, 85 & 8,408 & $<0,001$ \\
\hline 15 & Tossing a ring over a peg & 11 & 9,05 & 2,94 & 11,05 & 2,39 & $-2,387$ & $<0,022$ \\
\hline & & 12 & 10,17 & 2,37 & 9,70 & 2,62 & ,619 & $>0,540$ \\
\hline & & 13 & 10,58 & 2,43 & 11,42 & 2,48 & $-1,057$ & $>0,298$ \\
\hline 16 & Height (cm) & 11 & 143,00 & 6,49 & 142,67 & 5,73 &, 174 & $>0,862$ \\
\hline & & 12 & 148,96 & 7,18 & 151,40 & 6,56 & $-1,158$ & $>0,253$ \\
\hline & & 13 & 157,11 & 8,55 & 156,63 & 10,44 & ,153 & $>0,879$ \\
\hline 17 & Body weight (kg) & 11 & 35,80 & 7,76 & 34,62 & 6,48 &, 530 & $>0,599$ \\
\hline & & 12 & 39,37 & 10,45 & 44,10 & 7,88 & $-1,654$ & $>0,106$ \\
\hline & & 13 & 46,21 & 8,93 & 50,89 & 11,26 & $-1,420$ & $>0,164$ \\
\hline
\end{tabular}


The study protocol was approved by the Ethical Committee of H. S. Skovoroda Kharkiv National Pedagogical University. In addition, the children and their parents or legal guardians were fully informed about all the features of the study, and a signed informedconsent document was obtained from all the parents.

\section{Study results}

Table 1 shows the results of comparison between the coordination preparedness of the girls and boys aged 11-13. According to the anthropometric indices, the difference between the girls and boys is statistically insignificant ( $p>0.05)$.

The girls show statistically significantly better results in test 9 "Static equilibrium evaluation by $\mathrm{E}$. Ya. Bondarevsky's method" (12 years old). There is a statistically insignificant $(p>0.05)$ difference in the results of the tests evaluating running speed: test 6 "Evaluation of the sense of movement speed in sprinting", test 7 "Evaluation of the ability to differentiate movement speed (reproduction accuracy of running speed at $80 \%$ intensity of maximum)", test 8 "Evaluation of the ability to differentiate movement speed (reproduction accuracy of running speed at $90 \%$ intensity of maximum)". In tests 12,13 evaluating movement coordination of different parts of the body and in test 15 evaluating spatial accuracy of movements, the difference in the results of the girls and boys aged $11-13$ is statistically insignificant ( $p>0.05)$.

In tests $1,2,3,4,5,14$, the girls show statistically significantly worse results than the boys.

To clarify the peculiarities of coordination abilities development in the girls and boys aged 11-13, the study conducted a discriminant analysis. The results obtained during the discriminant analysis allow to identify the state of movement coordination development in the girls and boys (see Table 2-7).

The first canonical function explains $65.7 \%$ of the results variation, the second one $-25.1 \%$, the third $4.8 \%$, which indicates their informative value (see Table 2). The coefficients of canonical correlation indicate the prognostic value of these functions.

Table 2. Summary of Canonical Discriminant Functions. Eigenvalues. Girls and boys aged 11-13

\begin{tabular}{ccccc}
\hline Function & Eigenvalue & $\begin{array}{c}\% \text { of } \\
\text { Variance }\end{array}$ & $\begin{array}{c}\text { Cumulative } \\
\%\end{array}$ & $\begin{array}{c}\text { Canonical } \\
\text { Correlation }\end{array}$ \\
\hline 1 & $7.459 \mathrm{a}$ & 65.7 & 65.7 & .939 \\
2 & $2.851 \mathrm{a}$ & 25.1 & 90.8 & .860 \\
3 & $.542 \mathrm{a}$ & 4.8 & 95.6 & .593 \\
4 & $.372 \mathrm{a}$ & 3.3 & 98.9 & .521 \\
5 & $.127 \mathrm{a}$ & 1.1 & 100.0 & .336 \\
\hline
\end{tabular}

Table 3. Canonical discriminant functions. Wilks' Lambda. Girls and boys aged 11-13

\begin{tabular}{lcccc}
\hline Test of Function(s) & Wilks' Lambda & Chi-square & df & Sig. \\
\hline 1 through 5 & .013 & 476.662 & 85 & .000 \\
2 through 5 & .109 & 242.854 & 64 & .000 \\
3 through 5 & .419 & 95.201 & 45 & .000 \\
4 through 5 & .646 & 47.787 & 28 & .011 \\
5 & .887 & 13.139 & 13 & .437 \\
\hline
\end{tabular}

Table 3 shows the analysis of the canonical functions. The first line contains the value $\lambda=0.013$ ( $\mathrm{p}=0.001$ ) for the entire set of canonical functions, the second line contains the data after the exclusion of the first function $(\lambda=0.109 ; p=0.001)$, the third line - the data after the exclusion of the first and second functions $(\lambda=0.419$; $\mathrm{p}=0.001)$. The first, second, and third functions have a high discriminative ability and value of interpretation with regard to the general totality.

Table 4 shows the standardized canonical discriminant function coefficients, which allow to determine the contribution ratio of the variables to the function result.

- function 1: variables 4 (0.837), 14 (0.526), 2 $(-0.488)$ make the largest contribution to the canonical function;

- function 2: variables 2 (0.518), 16 (0.483), 12 $(-0.415), 9(0.370)$ make the largest contribution to the canonical function;

- function 3: variables 6 (0.696), 1 (0.432), 12 $(-0.390), 9(0.365)$ make the largest contribution to the canonical function;

- function 4 : variables 12 (0.395), 3 (-0.389), 2 (0.363) make the largest contribution to the canonical function;

- function 5: variables 10 (0.543), 5 (-0.414), $1(-0.377), 11(0.360)$ make the largest contribution to the canonical function.

In identifying the state of coordination abilities development in the girls and boys aged 11-13, the first canonical discriminant function is the most important one. By these variables characterizing the level of relative and speed strength development and the level of movement coordination development, it is possible to classify the girls and boys into groups.

Table 5 shows the structure coefficients of the canonical discriminant functions, which are the coefficients of correlation between the variables and the function. The first canonical discriminant function is most substantially related totheresults oftests $4(\mathrm{r}=0.526)$, $14(\mathrm{r}=0.377), 2(\mathrm{r}=-0.306)$ : thus, a significant difference between the girls and boys aged 11-13 is observed in the level of development of relative and speed strength and movement coordination. The structure coefficients of the second canonical discriminant function show that 
Table 4. Standardized Canonical Discriminant Function Coefficients. Girls and boys aged 11-13

\begin{tabular}{|c|c|c|c|c|c|c|}
\hline \multirow{2}{*}{ No } & \multirow{2}{*}{ Test } & \multicolumn{5}{|c|}{ Function } \\
\hline & & 1 & 2 & 3 & 4 & 5 \\
\hline 1. & $30 \mathrm{~m}$ running $(\mathrm{s})$ & .423 & -.099 & .432 & -.101 & -.377 \\
\hline 2. & Standing long jump (cm) & -.488 & .518 & .200 & .363 & .239 \\
\hline 3. & $\begin{array}{l}\text { Six standing accuracy ball handlings to a partner } \\
\text { from a } 7 \mathrm{~m} \text { distance using one of the techniques } \\
\text { learned }\end{array}$ & -.284 & -.078 & -.252 & -.389 & .206 \\
\hline 4. & Pull-ups (number of times) & .837 & .214 & -.235 & -.026 & .070 \\
\hline 5. & Sit-ups in 30 seconds & -.043 & .182 & -.382 & -.201 & -.414 \\
\hline 6. & $\begin{array}{l}\text { Evaluation of the sense of movement speed in } \\
\text { sprinting }\end{array}$ & -.174 & -.093 & .696 & .327 & .045 \\
\hline 7. & $\begin{array}{l}\text { Evaluation of the ability to differentiate movement } \\
\text { speed (reproduction accuracy of running speed at } \\
80 \% \text { intensity of maximum) }\end{array}$ & -.039 & .087 & .358 & -.253 & .144 \\
\hline 8. & $\begin{array}{l}\text { Evaluation of the ability to differentiate movement } \\
\text { speed (reproduction accuracy of running speed at } \\
90 \% \text { intensity of maximum) }\end{array}$ & .059 & .171 & -.121 & .067 & -.352 \\
\hline 9. & $\begin{array}{l}\text { Static equilibrium evaluation by E. Ya. } \\
\text { Bondarevsky's method }\end{array}$ & .095 & .370 & .365 & -.167 & -.016 \\
\hline 10. & $\begin{array}{l}\text { Evaluation of dynamic equilibrium by the BESS } \\
\text { method }\end{array}$ & -.079 & -.156 & .106 & -.044 & .543 \\
\hline 11. & $\begin{array}{l}\text { Evaluation of the ability for vestibular (statokinetic) } \\
\text { stability. Running with turns }\end{array}$ & .173 & .133 & .089 & .167 & .360 \\
\hline 12. & Rhythmic hand tapping & .020 & -.415 & -.390 & .395 & -.042 \\
\hline 13. & Rhythmic movements of upper and lower limbs & -.121 & -.167 & -.215 & .338 & -.332 \\
\hline 14. & Shuttle run $(4 \times 9 \mathrm{~m})$ & .526 & -.043 & -.244 & .045 & .205 \\
\hline 15. & Tossing a ring over a peg & -.068 & .055 & -.237 & -.331 & -.097 \\
\hline 16. & Height $(\mathrm{cm})$ & .141 & .483 & -.295 & .263 & .180 \\
\hline 17. & Body weight (kg) & -.111 & .001 & .319 & .179 & -.313 \\
\hline
\end{tabular}

the function is most substantially related to variables $2(\mathrm{r}=0.502), 16(\mathrm{r}=0.434), 9(\mathrm{r}=0.379), 17(\mathrm{r}=0.357)$ : thus, a significant difference between the girls aged 1213 and boys aged 11-13 is observed in speed strength, vestibular stability, and anthropometric data.

Table 6 shows the classification results of the groups, $93.4 \%$ of the original grouped observations were classified correctly. Therefore, the canonical discriminat function can be used to identify the state of movement coordination development in the girls and boys aged 11-13.

\section{Discussion}

The above-mentioned results give evidence of a statistically significant difference in the strength preparedness of the girls and boys aged 11-13, as well as in the results of movement coordination tasks that require speed and strength preparedness $(p<0.001)$ : the boys show better results. The girls have better results in vestibular stability than the boys. The girls' and boys' results of the tests evaluating temporal characteristics of movement, spatial accuracy, and movement coordination of different parts of the body do not statistically significantly differ ( $p>0.05$ ).

As a result of the discriminant function analysis, the study determined that to identify the level of coordination abilities development in boys aged 11, 12 and 13, the following tests can be used: test 9 "Static equilibrium evaluation by E. Ya. Bondarevsky's method" and test 14 "Shuttle run ( $4 \times 9 \mathrm{~m})$ ), which characterize vestibular stability and general movement coordination (Ivashchenko, Khudolii, Iermakov, \& Prykhodko, 2018). Unlike boys, to identify the level of coordination abilities development in girls aged 11, 12 and 13, it is advisable to use the tests that characterize relative and speed strength, the sense of running speed and vestibular stability (Ivashchenko, Khudolii, Iermakov, Prykhodko, \& Cieslicka, 2018).

The discriminant analysis of the girls' and boys' data allowed to obtain models that characterize both age- and gender-related peculiarities of movement coordination development. The study determined statistically significant differences between multidimensional mean values (centroids) in each group $(\mathrm{p}<0.001)$ (see Table 7 ). 
Table 5. Structure Matrix. Girls and boys aged 11-13

\begin{tabular}{|c|c|c|c|c|c|c|}
\hline \multirow{2}{*}{ No } & \multirow{2}{*}{ Test } & \multicolumn{5}{|c|}{ Function } \\
\hline & & 1 & 2 & 3 & 4 & 5 \\
\hline 4. & Pull-ups (number of times) & $.526^{\star}$ & .350 & -.164 & .028 & .081 \\
\hline 14. & Shuttle run $(4 \times 9 \mathrm{~m})$ & $.377^{\star}$ & -.165 & -.156 & .092 & .260 \\
\hline 2. & Standing long jump $(\mathrm{cm})$ & -.306 & $.502^{*}$ & -.100 & .283 & .194 \\
\hline 16. & Height $(\mathrm{cm})$ & .018 & $.434^{\star}$ & -.067 & .370 & .002 \\
\hline 9. & $\begin{array}{l}\text { Static equilibrium evaluation by E. Ya. Bondarevsky's } \\
\text { method }\end{array}$ & .123 & $.379^{*}$ & .228 & -.020 & -.191 \\
\hline 17. & Body weight (kg) & -.041 & $.357^{\star}$ & .071 & .356 & -.137 \\
\hline 6. & Evaluation of the sense of movement speed in sprinting & .020 & -.223 & $.398^{*}$ & .133 & -.127 \\
\hline 1. & $30 \mathrm{~m}$ running $(\mathrm{s})$ & .215 & -.207 & $.371^{\star}$ & -.085 & -.336 \\
\hline 12. & Rhythmic hand tapping & -.016 & -.318 & -.267 & $.505^{\star}$ & -.052 \\
\hline 13. & Rhythmic movements of upper and lower limbs & -.017 & -.117 & -.116 & $.390^{*}$ & -.283 \\
\hline 3. & $\begin{array}{l}\text { Six standing accuracy ball handlings to a partner from a } 7 \\
\mathrm{~m} \text { distance using one of the techniques learned }\end{array}$ & -.259 & -.004 & -.212 & $-.368^{*}$ & .100 \\
\hline 15. & Tossing a ring over a peg & -.043 & .117 & -.130 & $-.312^{\star}$ & -.154 \\
\hline 10. & Evaluation of dynamic equilibrium by the BESS method & -.017 & -.186 & .154 & .042 & $.426^{*}$ \\
\hline 5. & Sit-ups in 30 seconds & -.130 & .176 & -.236 & -.229 & $-.340^{*}$ \\
\hline 8. & $\begin{array}{l}\text { Evaluation of the ability to differentiate movement speed } \\
\text { (reproduction accuracy of running speed at } 90 \% \text { intensity } \\
\text { of maximum) }\end{array}$ & .051 & .154 & .044 & .009 & $-.316^{*}$ \\
\hline 11. & $\begin{array}{l}\text { Evaluation of the ability for vestibular (statokinetic) } \\
\text { stability. Running with turns }\end{array}$ & .108 & .094 & .049 & .069 & $.242^{*}$ \\
\hline 7. & $\begin{array}{l}\text { Evaluation of the ability to differentiate movement speed } \\
\text { (reproduction accuracy of running speed at } 80 \% \text { intensity } \\
\text { of maximum) }\end{array}$ & .019 & .101 & .173 & -.175 & $.178^{\star}$ \\
\hline
\end{tabular}

Table 6. Classification Resultsa. Girls and boys aged 11-13

\begin{tabular}{|c|c|c|c|c|c|c|c|c|c|}
\hline & \multirow{3}{*}{ Scale } & \multirow{3}{*}{ Group } & \multicolumn{6}{|c|}{ Predicted Group Membership } & \multirow[t]{3}{*}{ Total } \\
\hline & & & \multirow[b]{2}{*}{1.00} & \multicolumn{2}{|c|}{ Girls } & \multicolumn{3}{|c|}{ Boys } & \\
\hline & & & & 2.00 & 3.00 & 5.00 & 6.00 & 7.00 & \\
\hline \multirow{12}{*}{ Original } & \multirow{6}{*}{ Count } & 1.00 & 21 & 0 & 0 & 0 & 0 & 0 & 21 \\
\hline & & 2.00 & 1 & 19 & 0 & 0 & 0 & 0 & 20 \\
\hline & & 3.00 & 0 & 1 & 18 & 0 & 0 & 0 & 19 \\
\hline & & 5.00 & 0 & 0 & 0 & 19 & 1 & 0 & 20 \\
\hline & & 6.00 & 0 & 0 & 0 & 1 & 20 & 2 & 23 \\
\hline & & 7.00 & 0 & 0 & 0 & 1 & 1 & 17 & 19 \\
\hline & \multirow{6}{*}{$\%$} & 1.00 & 100.0 & .0 & .0 & .0 & .0 & .0 & 100.0 \\
\hline & & 2.00 & 5.0 & 95.0 & .0 & .0 & .0 & .0 & 100.0 \\
\hline & & 3.00 & .0 & 5.3 & 94.7 & .0 & .0 & .0 & 100.0 \\
\hline & & 5.00 & .0 & .0 & .0 & 95.0 & 5.0 & .0 & 100.0 \\
\hline & & 6.00 & .0 & .0 & .0 & 4.3 & 87.0 & 8.7 & 100.0 \\
\hline & & 7.00 & .0 & .0 & .0 & 5.3 & 5.3 & 89.5 & 100.0 \\
\hline
\end{tabular}

$93.4 \%$ of the original grouped cases correctly classified 
Table 7. Functions at Group Centroids*. Girls and boys aged 11-13

\begin{tabular}{|c|c|c|c|c|c|}
\hline \multirow{2}{*}{ Group } & \multicolumn{5}{|c|}{ Function } \\
\hline & 1 & 2 & 3 & 4 & 5 \\
\hline Girls aged 11 & -2.327 & -1.331 & -.547 & -.954 & .171 \\
\hline Girls aged 12 & -2.535 & -.385 & -.479 & 1.066 & .243 \\
\hline Girls aged 13 & -3.049 & 2.429 & .634 & -.141 & -.365 \\
\hline Boys aged 11 & 1.350 & -1.983 & 1.309 & .090 & .072 \\
\hline Boys aged 12 & 2.808 & -.557 & -.654 & .117 & -.517 \\
\hline Boys aged 13 & 3.468 & 2.209 & -.112 & -.163 & .470 \\
\hline
\end{tabular}

*Unstandardized canonical discriminant functions evaluated at group means

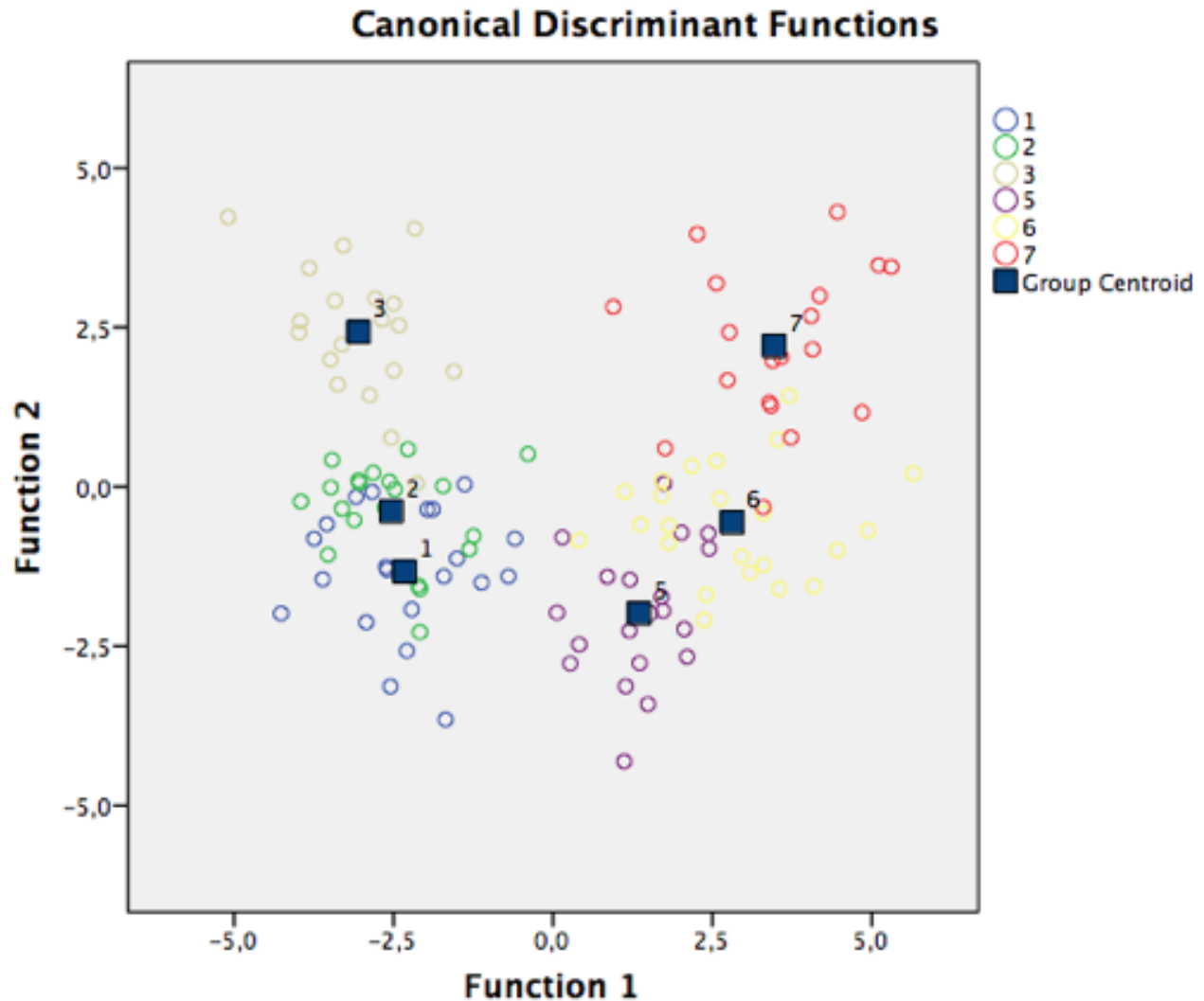

Figure 1. Graphical representation of the classification results (girls: 1 - aged 11, 2 - aged 12, 3 - aged 13; boys: 5 - aged 11,6 - aged 12,7 - aged 13)

The graphical material shown in Figure 1 indicates the density of objects in each group and a distinct boundary between them. This makes it possible to argue that the girls and boys aged 11-13 can be classified based on the results of testing using the battery of tests provided.

All the above speak to the existence of substantial differences between the groups of girls and boys aged 11-13 both in the structure of coordination abilities development and the level of preparedness, and highlight the need to conduct separate physical education classes for girls and boys. Different programs should be used for developing coordination abilities in boys and girls aged 11-13.
The above-mentioned results show that discriminant analysis allows to identify the state of coordination abilities development in the girls and boys aged 11-13 by the results of testing, and supplement the data on the use of discriminant function in classifying schoolchildren by motor activity (Gert-Jan de Bruijn, \& Benjamin Gardner, 2011; Lulzim, 2013). As well as in the works by Geoffrey, and Gabie (1982), Ivashchenko, Iermakov, and Khudolii (2017), the study observed a high discriminative and predictive ability of these functions in evaluating age- and gender-related peculiarities of coordination abilities development in the girls and boys aged 11-13. 
Table 8. Canonical Discriminant Function Coefficients (Unstandardized coefficients).

\begin{tabular}{|c|c|c|c|c|c|c|}
\hline \multirow{2}{*}{ No } & \multirow{2}{*}{ Test } & \multicolumn{5}{|c|}{ Function } \\
\hline & & 1 & 2 & 3 & 4 & 5 \\
\hline 1. & $30 \mathrm{~m}$ running $(\mathrm{s})$ & 1.066 & -.249 & 1.090 & -.253 & -.951 \\
\hline 2. & Standing long jump $(\mathrm{cm})$ & -.047 & .050 & .019 & .035 & .023 \\
\hline 3. & $\begin{array}{l}\text { Six standing accuracy ball handlings to a partner from a } 7 \\
\mathrm{~m} \text { distance using one of the techniques learned }\end{array}$ & -.268 & -.074 & -.238 & -.367 & .194 \\
\hline 4. & Pull-ups (number of times) & .469 & .120 & -.132 & -.015 & .039 \\
\hline 5. & Sit-ups in 30 seconds & -.009 & .040 & -.083 & -.044 & -.090 \\
\hline 6. & Evaluation of the sense of movement speed in sprinting & -1.371 & -.732 & 5.471 & 2.575 & .357 \\
\hline 7. & $\begin{array}{l}\text { Evaluation of the ability to differentiate movement speed } \\
\text { (reproduction accuracy of running speed at } 80 \% \text { intensity } \\
\text { of maximum) }\end{array}$ & -.340 & .761 & 3.154 & -2.222 & 1.265 \\
\hline 8. & $\begin{array}{l}\text { Evaluation of the ability to differentiate movement speed } \\
\text { (reproduction accuracy of running speed at } 90 \% \text { intensity } \\
\text { of maximum) }\end{array}$ & .674 & 1.941 & -1.380 & .761 & -3.995 \\
\hline 9. & $\begin{array}{l}\text { Static equilibrium evaluation by E. Ya. Bondarevsky's } \\
\text { method }\end{array}$ & .010 & .038 & .037 & -.017 & -.002 \\
\hline 10. & Evaluation of dynamic equilibrium by the BESS method & -.011 & -.021 & .014 & -.006 & .072 \\
\hline 11. & $\begin{array}{l}\text { Evaluation of the ability for vestibular (statokinetic) } \\
\text { stability. Running with turns }\end{array}$ & .162 & .125 & .084 & .156 & .338 \\
\hline 12. & Rhythmic hand tapping & .014 & -.286 & -.269 & .272 & -.029 \\
\hline 13. & Rhythmic movements of upper and lower limbs & -.113 & -.155 & -.200 & .314 & -.309 \\
\hline 14. & Shuttle run $(4 \times 9 \mathrm{~m})$ & .529 & -.043 & -.246 & .045 & .206 \\
\hline 15. & Tossing a ring over a peg & -.027 & .022 & -.093 & -.130 & -.038 \\
\hline 16. & Height $(\mathrm{cm})$ & .019 & .064 & -.039 & .035 & .024 \\
\hline 17. & Body weight (kg) & -.012 & .000 & .036 & .020 & -.035 \\
\hline & (Constant) & -10.933 & -15.306 & -1.236 & -9.599 & -2.765 \\
\hline
\end{tabular}

To practically apply the results of discriminant analysis, the canonical discriminant function coefficients are used (see Table 8). The probability of a case belonging to the predicted group is calculated by substituting the values of variables that correspond to the case into the discriminant function. By comparing the obtained results with the value of centroids, it is possible to determine the group the result belongs to (Table 7). To classify the preparedness state of the girls and boys aged 11-13, the first and second functions are used.

The above-mentioned data supplement the results:

- Agricola et al. (2015), Palomo-Nieto et al. (2015) on the importance of movement coordination of different parts of the body in evaluating children's and adolescents' coordination abilities;

- Volkov, and Nagovitsyn (2018) about the influence of motor activity and purposeful usage of physical education means on a positive dynamics of movement coordination development in children and adolescents;

- Meadmore, Exell, Burridge, Hughes, Freeman, and Benson (2018) on the gender differences in children related to the body composition and movement coordination.

During the analysis, the study confirmed Ivashchenko's (2016) conclusions as to the usage of factor analysis for the evaluation of the current state of motor preparedness, and the usage of discriminant analysis for the evaluation of the state dynamics in the age range, which makes it possible to determine informative indicators for a comprehensive control of motor preparedness.

\section{Conclusions}

The discriminant analysis made it possible to determine informative indicators for a comprehensive control of coordination abilities development in the girls and boys aged 11-13; to answer the question of whether the difference between the states of coordination abilities development of the girls and boys aged 11-13 is significant; what motor tests most substantially influence the differentiation of classes; what class the object belongs to based on the values of discriminant variables.

The discriminant models characterize both age- and gender-related peculiarities of movement coordination 
development in the girls and boys aged 11-13. The data obtained show significant differences between the groups of girls and boys aged 11-13 both in the structure of coordination abilities development and the level of preparedness, and highlight the need to conduct separate physical education classes for girls and boys. Different programs should be used for developing coordination abilities in boys and girls aged 11-13.

The prospect for further exploration is to study methodological approaches to programming the coordination abilities development in schoolchildren of middle school age.

\section{Acknowledgement}

The study was carried out within the topic 13.04 "Modeling of teaching and motor skills development in children and adolescents" (2013-2014) (state registration number 0113U002102).

\section{Conflict of interest}

The authors declare no conflict of interest.

\section{References}

Bădicu, G. (2018). Physical Activity and Health-Related Quality of Life in Adults from Braşov, Romania. Education Sciences, 8(2). https://doi.org/10.3390/educsci8020052

Bădicu, G., \& Balint, L. (2016). The influence of leisure sports activities on social health in adults. SpringerPlus, 5(1), 1647. https://doi.org/10.1186/s40064-016-3296-9

Balsevich, V.K. (2000). Ontokinesiology of man. M.: Theory and practice of physical culture, 275. (in Russian).

Ilyin, E. P. (2003). Psychomotor organization of man: training. for universities. St. Petersburg. : Peter, 384. (in Russian)

Ivashchenko, O.V. (2016). Modelling of physical education students: Monograph. Kharkiv: OVS (in Ukrainian)

Emeljanovas, A., Mieziene, B., \& Putriute, V. (2015). The Relationship Between Physical Activity and Content of the Physical Education Classes in 11-12 Years Old Lithuanian Schoolchildren. The Pilot Study. Croatian Journal of Education-Hrvatski Casopis Za Odgoj I Obrazovanje, 17(1), 93-120.

Han,A., Fu, A., Cobley, S.,\&SandersR. H. (2017). Effectiveness of exercise intervention on improving fundamental movement skills and motor coordination in overweight/obese children and adolescents: A systematic review. Journal of Science and Medicine in Sport, 21(1),89-102. https://doi.org/10.1016/j.jsams.2017.07.001

Liakh, V. I. (2000). Driving abilities of schoolchildren: Fundamentals of theory and methods of development. M.: Terra-Sport, 192. (in Russian)

Krutsevych, T. Yu., \& Bezverkhnia, H. V. (2010). Recreation in the physical culture of different population groups: teaching. manual. K. : Olimpiiska literatura, 248. (in Ukrainian)

Khudolii, O.M., Ivashchenko, O.V., \& Chernenko, S.O. (2015). Simulation of junior shcoolchildren's training to acrobatic exercises and vaults. Pedagogics, Psychology, Medical-Biological Problems Of Physical Training And Sports, 19(7), 64-71.

https://doi.org/10.15561/18189172.2015.0709

Kapkan, O.O. (2015). Features of 14-15 years' age boys' training to physical exercises. Pedagogics, Psychology, Medical-Biological Problems Of Physical Training And Sports, 19(9), 26-32.

https://doi.org/10.15561/18189172.2015.0904

Iadreev, V., Cherkashin, I., Vujkov, S., \& Drid, P. (2015). Differences in anthropometric, motoric and cognitive abilities between athletically trained and untrained girls. Biomedical Human Kinetics, 7(1),73-77. https://doi.org/10.1515/bhk-2015-0012

Novak, D., Podnar, H., Emeljanovas, A., \& Marttinen, R. (2015). Comparison of Fitness Levels between Croatian and Lithuanian Students. Montenegrin Journal of Sports Science and Medicine, 4(1), 5-11.

Drid, P., Vujkov, S., Jaksic, D., Trivic, T., Marinkovic, D., \&Bala, G. (2013). Differences in Motor and Cognitive Abilities of Children Depending on Their Body Mass Index and Subcutaneous Adipose Tissue. Collegium Antropologicum, 37(2), 171-177.

Agricola, A., Psotta, R., Abdollahipour, R., \& Nieto, M. P. (2015). The differences of movement between children at risk of developmental coordination disorder and those not at risk. Acta Gymnica, 45(3), 129-138. https://doi.org/10.5507/ag.2015.007

Palomo-Nieto, M., Psotta, R., Agricola, A., Abdollahipour, R., \& Valtr, L. (2015). The effects of various visual conditions on the gait cycle in children with different level of motor coordination - a pilot study. RicydeRevista Internacional De Ciencias Del Deporte, 11(42), 387-399. https://doi.org/10.5232/ricyde2015.04207

Hadžić, R., Bjelica, D., Vujović, D., \& Popović, S. (2015). Effects of high-low aerobic program on transformation of motor skills at high school students. Sport Science, 8(1), 79-84

Khudolii, O.M., \& Ivashchenko, O.V. (2014). Simulation of the learning process and development of motor abilities in children and adolescents: Monograph. Kharkiv : OVS, 320. (in Ukrainian)

Lopatiev, A., Ivashchenko, O., Khudolii, O., Pjanylo, Y., Chernenko, S. \& Yermakova, T. (2017). Systemic approach and mathematical modeling in physical education and sports. Journal of Physical Education and Sport (JPES), 17(1), suplement, 146-155

Doğan, İ., Işik, Ö., \& Ersöz, Y. (2016). Examining the Turkish Men's Professional Basketball Team's Success According to Game-related Statistics with Discriminant Analysis. International Journal of Performance Analysis in Sport, 16(3), 829-836.

https://doi.org/10.1080/24748668.2016.11868931 
Miarka, B., Fukuda, D.H., Del Vecchio, F.B.,\& Franchini, E. (2016). Discriminant analysis of technical-tactical actions in high-level judo athletes. International Journal of Performance Analysis in Sport,16(1), 30-39. https://doi.org/10.1080/24748668.2016.11868868

Serhiienko, L. P. (2001). Testing of motor abilities of schoolchildren. K.: Olimpiiska literatura, 439. (in Ukrainian)

Gert-Jan de Bruijn, \& Benjamin Gardner (2011). Active Commuting and Habit Strength: An Interactive and Discriminant Analyses Approach. American Journal of Health Promotion, 25(3), e27-e36. https://doi.org/10.4278/ajhp.090521-QUAN-170

Lulzim, I. (2013). Discriminant analysis of morphologic and motor parameters of athlete and non athlete girl pupils of primary school on age 14 to 15 years. RIK(2012), 40(2), 185-190. http://fsprm.mk/wpcontent/uploads/2013/08/Pages-from-Spisanie-RIKbr.-2-2012-9.pdf

Geoffrey D. Broadhead, \& Gabie E. Church (1982). Discriminant Analysis of Gross and Fine Motor Proficiency Data. Perceptual and Motor Skills, 55(2), 547-552. https://doi.org/10.2466/pms.1982.55.2.547

Ivashchenko, O.V., Khudolii, O.M., Iermakov, S.S., \& Prykhodko, V.V. (2018). Coordinating abilities: recognition of a state of development of 11-13 years old boys. Pedagogics, Psychology, Medical-Biological
Problems Of Physical Training And Sports, 22(2), 86-91. https://doi.org/10.15561/18189172.2018.0204

Ivashchenko, O.V., Iermakov, S.S., \& Khudolii, O.M. (2017). The peculiarities of motor fitness' classification model of 6-10 years old girls. Pedagogics, Psychology, MedicalBiological Problems Of Physical Training And Sports, 21(6), 260-265. https://doi.org/10.15561/18189172.2017.0601

Ivashchenko, O., Khudolii, O., Iermakov, S., Prykhodko, V., \& Cieslicka, M. (2018). Movement Coordination: Identification of Age-Related Dynamics of its Development in Girls Aged 11-13. Teoriâ Ta Metodika Fizičnogo Vihovannâ, 18(2), 93-99. https://doi.org/10.17309/tmfv.2018.2.06

Volkov, P.B., \& Nagovitsyn, R.S. (2018). Gaming technologies in the development of spine flexibility and the coordination of children and teenagers' movements in sports classes in country health camps. Pedagogics, Psychology, Medical-Biological Problems Of Physical Training And Sports, 22(1), 50-55. https://doi.org/10.15561/18189172.2018.0107

Meadmore, Katie L., Exell, Timothy A., Burridge, Jane H., Hughes, Ann-Marie, Freeman, Christopher T., \& Benson, Valerie (2018). Upper limb and eye movement coordination during reaching tasks in people with stroke. Disability and Rehabilitation, 40(20), 24242432. https://doi.org/10.1080/09638288.2017.1336649

\title{
КООРДИНАЦІЯ РУХІВ: РОЗПІЗНАННЯ ОСОБЛИВОСТЕЙ РОЗВИТКУ У ДІВЧАТ І ХЛОПЦІВ 11-13 РОКІВ
}

\author{
Іващенко О. ${ }^{1}$, Худолій О. ${ }^{1}$, Єрмаков С. ${ }^{2}$, Бартік П. ${ }^{3}$, Приходько В.В. ${ }^{4}$ \\ ${ }^{1}$ Харківський національний педагогічний університет імені Г.С. Сковороди, Україна \\ ${ }^{2}$ Гданський університет фізичного виховання і спорту, Польща \\ ${ }^{3}$ Університет Матея Беля, Банська Бистриця, Словаччина \\ ${ }^{4} \mathrm{HBК} \mathrm{«Старт-школа»,} \mathrm{м.} \mathrm{Харків,} \mathrm{Україна}$
}

Реферат. Стаття: 8 с., 8 табл., рис. 1, 24 джерел.

Мета дослідження - визначити можливість розпізнання стану розвитку координаційних здібностей у дівчат і хлопців 11-13 років на основі методології багатовимірних статистик.

Матеріали і методи. У дослідженні прийняли участь дівчата: $11(\mathrm{n}=20), 12(\mathrm{n}=23), 13(\mathrm{n}=19)$ років; хлопці: $11(\mathrm{n}=21), 12(\mathrm{n}=20), 13(\mathrm{n}=19)$ років.

У роботі використані аналіз й узагальнення даних наукової літератури, тестування, дискримінантний аналіз.

Результати дослідження. Перша канонічна функція пояснює варіацію результатів на $65,7 \%$, друга - на $25,1 \%$, третя - на $4,8 \%$, що свідчить про ï інформативність. Коефіцієнти канонічної кореляції вказують на прогностичність вказаних функціiі. Перша канонічна дискримінантна функція най- більш суттєво зв’язана 3 результатами тестів № 4 $(\mathrm{r}=0,526), 14(\mathrm{r}=0,377), 2$ ( $\mathrm{r}=-0,306)$ : отже суттєва різниця між дівчатами і хлопцями 11-13 років спостерігається у рівні розвитку відносної і швидкісної сили, координації рухів. Структурні коефіцієнти другої канонічної дискримінантної функції вказують, що функція найбільш суттєво зв'язана зі змінними № 2 ( $\mathrm{r}=0,502), 16(\mathrm{r}=0,434), 9(\mathrm{r}=0,379)$, $17(\mathrm{r}=0,357)$ : отже суттєва різниця між дівчатами 12-13 років і хлопцями 11-13 років спостерігається в швидкісній силі, вестибулярній стійкості і антропометричних даних.

Висновки. Дискримінантні моделі характеризують як вікові, так і гендерні особливості розвитку координації рухів у дівчат і хлопців 11-13 років. Отримані данні свідчать про суттєві розбіжності 
між групами дівчат і хлопців 11-13 років як у структурі розвитку координаційних здібностей, так і в рівні підготовленості, та вказують на необхідність проведення уроків фізичної культури окремо для дівчат і хлопців. Розвиток координаційних здібнос- тей у дівчат і хлопців 11-13 років повинен здійснюватися за різними програмами.

Ключові слова: дискримінантний аналіз, координаційні здібності, наскрізний контроль, дівчата, хлопці.

\title{
КООРДИНАЦИЯ ДВИЖЕНИЙ: РАСПОЗНАВАНИЕ ОСОБЕННОСТЕЙ РАЗВИТИЯ У ДЕВОЧЕК И МАЛЬЧИКОВ 11-13 ЛЕТ
}

\author{
Иващенко О. ${ }^{1}$, Худолей О. ${ }^{1}$, Ермаков С. ${ }^{2}$, Бартик П. ${ }^{3}$, Приходько В.В. ${ }^{4}$ \\ ${ }^{1}$ Харьковский национальный педагогический университет имени Г.С. Сковороды, \\ Украина \\ ${ }^{2}$ Гданьский университет физического воспитания и спорта, Польша \\ ${ }^{3}$ Университет Матея Беля, Банска Быстрица, Словакия \\ ${ }^{4}$ УВК «Старт-школа», г. Харьков, Украина
}

Реферат. Статья: 11 с., 8 табл., рис. 1, 24 источников.

Цель исследования - определить возможность распознавания состояния развития координационных способностей у девочек и мальчиков 11-13 лет на основе методологии многомерных статистик.

Материалы и методы. В исследовании приняли участие девочки: $11(\mathrm{n}=20), 12(\mathrm{n}=23), 13(\mathrm{n}=19)$ лет; мальчики: $11(\mathrm{n}=21), 12(\mathrm{n}=20), 13(\mathrm{n}=19)$ лет.

B работе использованы анализ и обобщение данных научной литературы, тестирование, дискриминантный анализ.

Результаты исследования. Первая каноническая функция объясняет вариацию результатов на $65,7 \%$, вторая - на $25,1 \%$, третья - на $4,8 \%$, что свидетельствует об их информативность. Коэффициенты канонической корреляции указывают на прогностичность указанных функции. Первая каноническая дискриминантная функция наиболее существенно связана с результатами тестов № $4(\mathrm{r}=$ $0,526), 14(\mathrm{r}=0,377), 2(\mathrm{r}=-0,306)$ : значит существенная разница между девочками и мальчиками 11-13 лет наблюдается в уровне развития относительной и скоростной силы, координации движений. Структурные коэффициенты второй канонической дискриминантной функции указывают, что функция наиболее существенно связана с переменными № $2(\mathrm{r}=0,502), 16(\mathrm{r}=0,434), 9(\mathrm{r}=0,379), 17(\mathrm{r}=$ $0,357)$ : значит существенная разница между девочками 12-13 лет и мальчиками 11-13 лет наблюдается в скоростной силе, вестибулярной устойчивости и антропометрических данных.

Выводы. Дискриминантные модели характеризуют как возрастные, так и гендерные особенности развития координации движений у девочек и мальчиков 11-13 лет. Полученные данные свидетельствуют о существенных различиях между группами девочек и мальчиков 11-13 лет как в структуре развития координационных способностей, так и в уровне подготовленности, и указывают на необходимость проведения уроков физической культуры отдельно для девочек и мальчиков. Развитие координационных способностей у девочек и мальчиков 11-13 лет должно осуществляться по различным программам.

Ключевые слова: дискриминантный анализ, координационные способности, сквозной контроль, девочки, мальчики. 


\section{Information about the authors:}

\section{Ivashchenko $\mathbf{O}$.}

olga@tmfv.com.ua

https://orcid.org/0000-0002-2708-5636

Department of Theory and Methodology of Physical

Education, Health and Medical Physical Culture,

H. S. Skovoroda Kharkiv National Pedagogical University,

Ukraine,

street Alchevskikh, 29, Kharkiv, 61003, Ukraine.

\section{Khudolii $\mathbf{O}$.}

khudolii.oleg@gmail.com

http://orcid.org/0000-0002-5605-9939

Department of Theory and Methodology of Physical

Education, Health and Medical Physical Culture,

H. S. Skovoroda Kharkiv National Pedagogical University,

Ukraine,

street Alchevskikh, 29, Kharkiv, 61003, Ukraine.

Iermakov S.

sportart@gmail.com

http://orcid.org/0000-0002-5039-4517

Department of Tourism and Recreation, Gdansk University

of Physical Education and Sport, Poland

street Kasimir Gorskogo 1, 80-336 Gdansk, Poland.

\section{Bartík P.}

pavol.bartik@umb.sk https://orcid.org/0000-0002-2087-7876

Department of Physical Education and Sports, Matej Bel University, Banska Bystrica, Slovakia.

Tajovského 40, 97401 Banská Bystrica, Slovakia.

Prykhodko V.

vladimir3733614@gmail.com

https://orcid.org/0000-0002-9095-0573

Start-School, Kharkiv, Ukraine,

street Sadova, 20, Kharkov, 61000, Ukraine.

Cite this article as: Ivashchenko, O., Khudolii, O., Iermakov, S., Bartík, P., \& Prykhodko, V. (2018). Movement Coordination: Identification of Development Peculiarities in Girls and Boys Aged 11-13. Teoriâ ta Metodika Fizičnogo Vihovannâ [Theory and Methods of the Physical Education], 18(3), 136-147. https://doi.org/10.17309/tmfv.2018.3.04.

Received: 15.08.2018. Accepted: 15.09.2018. Published: 25.09.2018 